\title{
A Review on the Impact of Abiotic Stress on Plant Growth and Crop Production
}

\author{
Deepak Kochar*, Sushil and Rahul \\ Department of Soil Science, C.C.S. Haryana Agricultural University, Hisar (Haryana), India \\ *Corresponding author
}

\section{A B S T R A C T}

\begin{tabular}{l} 
K e y w o r d s \\
Abiotic stress, High \\
temperature, \\
Photosynthesis, \\
Transpiration, \\
Cellular changes, \\
etc. \\
\hline Article Info \\
$\begin{array}{l}\text { Accepted: } \\
\text { 22 June } 2020 \\
\text { Available Online: } \\
\text { 10 July } 2020\end{array}$ \\
\hline
\end{tabular}

Abiotic stress includes extreme temperature, salinity, drought, waterlogging, etc. highly influenced the plant growth in affected area. Abiotic stress reduced the development of plant which ultimately results in reduction in yield. Agricultural crops are highly influenced by abiotic stress which is due to the continue change of climate and deterioration of environment caused by human activity. Plants activities such as photosynthesis, flowering, pollination, transpiration, etc. affected by different abiotic stress experienced by plants at these stages. High temperature results in increase in transpiration rate which cause water stress in plant cell. Similarly, high salt condition in the root zone affects the osmotic potential of plant root cell which results in exosmosises in plant root cell. Waterlogging condition decreases the respiration rate of roots and produces methane gas which is a major gas responsible for climate change. However, to overcome the effects of abiotic stress, plant has developed a number of physiological and cellular changes in their life mechanism. Also, efficient resource management helps in reducing the impact of these abiotic stresses on crop. However, these management practices being long drawn and cost effectives, there is a need to develop simple and low cost strategies for abiotic stress management.

\section{Introduction}

In the past few years, the impact of abiotic stress on agricultural crop increases day by day. Climate change and human activity negatively affects the environment, which are the main cause of increasing abiotic stress. Various abiotic stresses such as high winds, extreme temperature, salinity, drought and waterlogging have affected the production and cultivation of agriculture crop (Shrivastava and Kumar, 2015). Abiotic stress has been becoming a major threat to food security now a day. The rate of plant growth and development is depends on the environmental conditions surrounding the plant. Extreme climatic conditions become a serious challenge for crop production and are predicted to increase under future climate scenario (Barlow et al., 2015). The emergence of abiotic stresses is often triggered by anomalous climatic conditions, such critical low and high temperatures, persistent absence of rain, extreme precipitation intensities, or high radiation intensities. Heat waves or extreme temperature events are projected to 
become more intense, more frequent, and last longer than what is being currently been observed in recent years. Extreme events such as high temperature occurring during the summer period would have the most dramatic impact on plant productivity (Kumudini et al., 2014). A progressive increase in the temperature in all over the major cropping countries was observed by Lobbel et al., 2011.

High temperature results in increase in the transpiration loss from plant and evaporation loss from soil which cause water stress in plant. Also, high and low temperature stress during flowering and reproductive stage affects the crop yield (Bita and Gerats, 2015). Low temperature similar to high temperature also affects plants growth and productivity. Temperate plant required a minimum temperature for flowering and fruiting. However, temperature below that particular temperature affects the growth of plant. Low temperature results in freezing of water in plant cell and damage cell wall causes chilling injury to plant (Sanghera et al., 2011). Frost and hail during the flowering and fruiting stage damage the crop and increase disease and pest attack in crop.

In arid or semiarid environments, where rainfall is very less and evaporation rate is very high, high concentration of salt reduced the plant root growth. High concentration of salt decreases the osmotic potential and cause exosmosises in the plant root.

The high concentration of salt also affects the nutrient uptake and results in nutrient deficiency in plants. Similar to salt affected soil, submerged soil also affect the root growth. In submerged condition, respiration rate of plant root is reduced and nutrient change into unavailable form. Continue submerged soil green-house gases which results in increase the temperature of earth.

\section{Extreme temperature stress}

Greaves (1996) defines suboptimal temperature stress as any reduction in growth or induced metabolic, cellular or tissue injury that results in limitations to the genetically determined yield potential, caused as a direct result of exposure to temperatures above or below the thermal thresholds for optimal biochemical and physiological activity or morphological development. For each crop, a particular range of temperature is required for optimum growth (Hatfield and Prueger, 2015). Temperature above or below this range significantly affects the yield of crop. Vegetative development increase as the temperature increases up to an optimum level. Extreme temperature condition at flowering and reproductive stage is studied all over the world. High temperature at grain filling stage in wheat crop is one of the factors which negatively affect the yield (Lou, 2011). Photosensitive crop such as soybean highly depends on temperature for its physiological development. Extreme temperature at reproductive stage results in lesser pollen viability, less fertilization and lesser fruit and pod development (Hatfield et al., 2011). Dupis and Dumas (1990) observed that the viability of pollen is decreased with rise in temperature above $35{ }^{\circ} \mathrm{C}$ in maize crop. The potential growth rate and size of the maize kernel was reduced with rise in temperature from $30{ }^{\mathrm{O}} \mathrm{C}$ to $35{ }^{\mathrm{O}} \mathrm{C}$ during endosperm development stage. Exposure of temperature above $30{ }^{\circ} \mathrm{C}$ to maize crop reduced the cell division rate and amyloplast replication in kernel which ultimately reduced the yield of maize crop (Commuri and Jones, 2001).

Rice shows similar trend as that of maize because pollen viability in rice decrease when daily mean temperature exceed above $33{ }^{\circ} \mathrm{C}$ (Kim et al., 1996). At heading, the fertility of spikelet was decline from 90 to $20 \%$ and to $0 \%$ when plant was exposed to $38{ }^{\circ} \mathrm{C}$ for 2 hours and $40{ }^{\circ} \mathrm{C}$ for 1hours (Yoshida, 1981). 
The sensitivity of crop to temperature depends on the length of anthesis. Some crop like mage have 3-5 days period of anthesis while rice and other small grain crop have 810 days of anthesis. Therefore, high temperature at this period affects the fertility and pollination of flower (Singh et al., 2015).Ferris et al. (1998) reported that grain yield of wheat varied from 3.7 to $9.5 \mathrm{Mg} / \mathrm{ha}$ as a result of differences in maximum temperature imposed during a 12-day period starting 7-9 days before 50\% anthesis. The effect of high temperature was highest (46\%) during stem elongation stage, intermediate (27\%) during booting stage and lowest (15\%) during anthesis in wheat crop (Ugarte et al., 2007). Prasad et al. (2001) reported that the flowering in groundnut decrease when temperature rise above $37{ }^{\mathrm{O}} \mathrm{C}$ and no flowering when temperature reached above 40 ${ }^{\mathrm{O}} \mathrm{C}$. Kakaniet al. (2005) reported that air temperature above $32{ }^{\circ} \mathrm{C}$ reduces cotton pollen viability, and temperature above $29^{\circ} \mathrm{C}$ reduces pollen tube elongation. Pettigrew (2008) evaluated two cotton genotypes under a temperature regime $1^{\mathrm{O}} \mathrm{C}$ warmer than ambient temperatures and found lint yield was $10 \%$ lower in the warm regime.High temperature at night also affects the growth of plant. It reduces photosynthesis function, decreases the starch content and increase the respiration rate. Reduction in the photosynthetic rate was due to decrease in chlorophyll and nitrogen content in leaf. Also due to high respiration, the plant consumes stored photosynthate at rapid rate which reduces the development of plant (Mohammed et al., 2011).

Low temperature also affects the crop growth and development in similar way as that of high temperature. In most of the crop species, low temperature at the time of reproduction stage is more prominent than vegetative stage, which results in decline in yield due to pollen sterility (Zinn et al., 2010). The cold stress experienced by crop can be categorised in two forms (a) temperature below freezing and (b) temperature above freezing (non-freezing temperature) (Tuteja et al., 2011). Plants like soybean, tomato, etc. are sensitive to nonfreezing temperature. The chilling stress results in wilting, chlorosis, reduction in leaf area which leads to necrosis. Low temperature at night affects the respiration rate and biomass accumulation (Hatfield et al., 2011). Cold stress below freezing point damage the cell membrane due to dehydration associated with freezing. The integrity of intracellular organelles is also disrupted leading to the loss of compartmentalization, reduction and impairing of photosynthesis, protein assembly and general metabolic processes. In frost condition, the ground temperature decreases and wheat crop experienced $2-4{ }^{\mathrm{O}} \mathrm{C}$ lower than atmospheric temperature (Frederiks et al., 2008). Frost can affect the wheat crop from seedling to maturity and results in poor seedling growth and scorched appearance of leaf. In other crop, such as rice spikelet sterility was also observed because of low temperature at panical formation stage (Shimono et al., 2007).

\section{Salinity stress}

Saline soil becomes a major problem for agriculture production in recent years. The area of the saline soil is increasing day by days because of both natural and human activities such as irrigation system (Munns and Tester, 2008). A saline soil is generally defined as one in which the electrical conductivity (EC) of the saturation extract (ECe) in the root zone exceeds $4 \mathrm{dS} \mathrm{m}^{-1}$ (approximately $40 \mathrm{mM} \mathrm{NaCl}$ ) at $25{ }^{\circ} \mathrm{C}$, has exchangeable sodium less than $15 \%$ and $\mathrm{pH}$ below 8.5. Saline soils have a mixture of salts of Chloride, Sulfate, Sodium, Magnesium and Calcium ions with sodium chloride often dominant. The problem of salinity was dominant in arid and semi-arid region of the 
world, where the potential of evapotranspiration exceed rainfall and there is sufficient rain to leach the salt from root zone (Vijayalakshmi, 2018). But it also found in coastal area in small amount where salt is deposit by sea water.It has been observed that worldwide $20 \%$ of total cultivated and $33 \%$ of irrigated agricultural lands are affected by high salinity. Also, the salinized areas are increasing at a rate of $10 \%$ annually for various reasons, including low precipitation, high surface evaporation, weathering of native rocks, irrigation with saline water, and poor cultural practices (Shrivastava and Kumar, 2015). In India alone, 7 million hectares of land are salt affected. Tamil Nadu, which is one of the strong rice cultivation areas in India, is prone to salinity stress.

Salinity affects the growth of plants mainly by two stresses: osmotic stress and ions toxicity. The movement of water in plant root take place due to high osmotic pressure at outside. High salt concentration in root zone decrease the osmotic potential of water in root surrounding and plant access to water is decreased. This water stress condition affects the stomata opening of plant leaves which decrease the entry of $\mathrm{CO}_{2}$ in plant (Parida and Das, 2005). Salinity affect the plant growth at all stages i.e. at germination, vegetative phase and at reproductive phase. Soil salinity results in ions toxicity $\left(\mathrm{Na}^{+}\right.$and $\left.\mathrm{Cl}^{-}\right)$and nutrients $(\mathrm{N}, \mathrm{P}, \mathrm{K}, \mathrm{Zn}$, and $\mathrm{Fe})$ deficiency. High concentration of $\mathrm{Na}^{+}$ion disturbs the metabolism process of plants and decreases the nitrate reductase activity and inhibits the functioning of photosystem II (Sheldon et al., 2017). Irrigation with saline water decreased the germination percentage, shoot dry weight of crop significantly and also decreased the seedling biomass production (Naim et al., 2012).

Abeeret al. (2014) reported that shoot length decreases to $40.23 \%$, number of branches per plant to $43.65 \%$, number of pods per plant to $81.60 \%$, pod dry weight to $85.71 \%$ and seed weight per plant decreased to $83.16 \%$ at 100 $\mathrm{mMNaCl}$ stress.High concentration of salt decreased the nitrogen fixing nodules, weight, leghemoglobin and nitrogenase activity (Egamberdieva et al., 2013). Saline water having EC less than $4 \mathrm{dSm}^{-1}$ had a positive effect of plant growth parameter while water having EC above than $4 \mathrm{dSm}^{-1}$ had negative effect on same parameter (Aydinsakir et al., 2015) in peanut crop. Increased salt concentration in soil results in decreased shoot, root, leaf area and increases root/shoot ratio in cotton (Meloni et al., 2001). Increase in epidermal thickness, mesophyll thickness, palisade cell length and decrease in mitochondria cristase and swelling of mitochondria with increasing concentration of salt was reported in cotton and sweet potato by Parida and Das (2004). Total carotenoid and chlorophyll content decrease whereas anthocyanin content increases with increase in salt stress. The older leaves develop chlorosis and fall down with prolonged period of salt stress. High salt uptake competes with the uptake of ions, especially $\mathrm{K}^{+}$, leading to deficiency of $\mathrm{K}^{+}$. Increasing concentration of $\mathrm{NaCl}$ increased the level of $\mathrm{Na}^{+}$and $\mathrm{Cl}^{-}$in plant cell and decreased the level of $\mathrm{Ca}^{2+}$ and $\mathrm{Mg}^{2+}$ (Khan, 2001). Ferreira et al., (2001) concluded a positive correlation between $\mathrm{Na}^{+}$ and $\mathrm{Cl}^{-}$and a negative correlation between $\mathrm{Na}^{+}$and $\mathrm{K}^{+}$concentration in leaves and root of guava.

\section{Drought stress}

Drought is defined by different scientist in different way. For a meteorologist, drought is a condition when there is prolonged time with less than average precipitation. Hydrological drought is a condition when rivers, lakes, aquifers and streams water level fall below a threshold level. However, for an agriculturist, drought is a condition of long dry period 
which affects the crop growth and crop yield (Vijaylakshmi, 2008). Another type of drought (physiological drought) is also common in saline condition where water is present in soil but not available to plant due to low osmotic potential. Water accounts for 80$95 \%$ of the fresh biomass of plant which play an important role in metabolic activities and development of plant (Hirt and Shinozaki, 2003). The severity of drought is unpredictable as it depends on many factors but it is more chronic in arid and semi-arid area where high temperature results in high evaporation loss from soil.

Drought is a multidimensional stress as it affects the physiological, biological and ecological activities of plants (Farooq et al., 2009). The effect of drought was increasing due to climate change. However, there is much other reason responsible for droughts such as high temperature, low and uneven rainfall distribution, high intensity of light (Lisar and Agdam, 2016). Drought severely reduces the growth and development of plants. Drought affects the plants from its germination stage causing water stress at that time. It reduces the germination of seed and results in poor seedling stand. Plant growth is depends on cell division, elongation and differentiation. All these phases are affected under drought condition by affecting cell turgor, enzyme activities and photosynthesis activity (Keyvan, 2010). The flow of water through xylem is interrupted by drought condition which reduced cell elongation. Reduction in cell elongation and cell division reduced the plant height and leaf area (Hussain et al., 2008). Turgor reduction affects the leaf expansion and growth. Decrease in leaf area decrease the number of stomata, thicken the cell wall, submersion of stomata in xerophyte plants that occur in plants due to drought condition. Optimum leaf area and number of stomata is needed for photosynthetic activity in plant (Jaleel et al., 2009). Therefore, decrease in leaf area and number of stomata reduced the net photosynthesis under drought. Decrease in photosynthesis decrease the plant growth and ultimately reduced the yield of crop.

Drought condition at anthesis, vegetative and reproductive phases significantly reduced the yield of crop. Samarah (2005)reported decreased in the number of tiller, grain per plant and grain weight in barley due to water stress condition at post-anthesis stage.Haoet al. (2013) reported that the chlorophyll content of drought-stressed soybean plants was reduced by $31 \%$ compared to nonstressed plants. In faba bean, DS considerably reduced the chlorophyll content, photosynthesis rate and impaired plant growth and yield (Saddiqui et al., 2015). Abidet al. (2017) reported that drought influences chlorophyll fluorescence and antioxidant enzyme activities in faba bean.

In maize crop, delay in silking and reduced number of kernel due to water stress condition was observed by Cattivelliet al. (2008). The process of grain felling in cereals is controlled by enzymes. Decreased in the activity of these enzymes was reported under drought stress which has negative impact on cereal yields (Fahad et al., 2017). Fang et al. (2010) reported decrease in yield of chick pea crop because of water stress at the time of pod development and flowering. Drought caused oxidative stress by the over-production of ROS $\left(\mathrm{O}^{2-}, \mathrm{H}_{2} \mathrm{O}_{2}, \mathrm{OH}^{-}\right)$and enhanced malondialdehyde contents, which led to reduced photosynthetic components, nutrients uptake ( $\mathrm{P}$ and $\mathrm{K}$ ) and yield attributes. The photosynthetic rate, respiration rate, stomatal conductance was reduced in both the maize hybrids due to drought condition (Hussain et al., 2019). Wang et al. (2020) reported that during moderate drought years in the period $1961-2017,3.2 \%$ and $10.4 \%$ of the provincial maize and soybean yields were lost, respectively. However, during more severe drought years, losses doubled for soybean 
(21.8\%), but increased more than four-fold for maize (14.0\%).Dong et al. 2019 observed that drought stress led to decreases in the $\mathrm{ZR} / \mathrm{IAA}$ and $\mathrm{ZR} / \mathrm{ABA}$ ratios in soybean leaves and an increase in the $\mathrm{ABA} /(\mathrm{IAA}+\mathrm{GA}+\mathrm{ZR})$ ratio; thus, the plant growth was inhibited and decrease the yield of crop.

\section{Water logging stress}

Water is required by plants for its growth and metabolic activities. It plays an important role in transpiration and photosynthesis. But, sometime excess of water is also harmful for plants under submerged or waterlogging condition. Waterlogging stress is another abiotic stress which adversely affects the crop production. Waterlogging is also a matter of worldwide concern affecting $16 \%$ of the soils in the United States, $10 \%$ of the agricultural lands of Russia and irrigated crop production areas of India, Pakistan, Bangladesh, and China (Manik et al., 2019). On a global scale, floods were the cause of almost two-thirds of all damage and loss to crops in the period between 2006 and 2016, with a value of billions of dollars.

Waterlogging condition disturbs the natural system of soil and affects the physical, chemical and biological characteristics of soil (Ferronato et al., 2019). Continues stagnation of water destroys the soil structure and makes the soil compact. Moist soil has lower temperature and higher specific heat than dry soil. Waterlogging stress is mainly prominent in soil of less infiltration rate, poor hydraulic conductivity and poor drainage conditions. Submerged condition result in a natural condition called hypoxia $\left(\mathrm{O}_{2}<21 \%\right)$ in soil (Sasidharan et al., 2017). As a result, plants root does not get sufficient oxygen to respire which result in substantial reduction in energy status of root cells. Under waterlogging condition, the concentration of $\mathrm{CO}_{2}$ (Greenway et al., 2006) increase which reduce the root growth. Submerged condition also affects the growth of plants by affecting the electron transport chain and Kreb's cycle in which oxygen play an important role (Ashraf, 2012). Waterlogging has a negative impact on photosynthesis by affects the chlorophyll content of the leaf. Since chlorophyll is an essential component of plant leaves which is responsible for excitation of electron in photosystem II and absorption of light. Therefore, change in the normal functioning of chlorophyll affects the photosystem II (Abdeshahian et al., 2010) which ultimately affects the photosynthesis.

Deficiency of oxygen due to submerged condition results in formation of ROS (superoxide, hydroxyl radical and hydrogen peroxide) in cells of plants. These species are highly reactive and damage the cellular structure and metabolites such as DNA, proteins, etc (Ashraf, 2009). There is a reversible $\mathrm{pH}$ change in waterlogged soil. In acidic soil, $\mathrm{pH}$ of soil increase and in alkaline soil $\mathrm{pH}$ decrease. Undoubtedly, the $\mathrm{pH}$ of soil is alters towards neutral in submerged condition. Due to change in $\mathrm{pH}$ and redox potential the activity of enzymes in plant and soil is decreased (Ashraf, 2012). In oilseed rape, the activity of urease decreased by 6.3 $\%$ and $24.4 \%$, phosphatase activity decreased by $9.8 \%$ and $29.6 \%$ while the activity of invertase decreased by $51 \%$ and $64.8 \%$ due to submerging condition ( $\mathrm{Gu}$ et al., 2019). Decrease in the activities of $\beta$-D-glucosidase and $\mathrm{N}$-acetyl- $\beta$-glucosaminidase during the flooded period when compared with other periods in a paddy field was reported by Kunito et al., 2018. Similarly, reduction in the activities of urease and phosphatase was reported by Bhattacharya et al. (2005) under submerged condition in paddy field.

The mineralisation and availability of nutrient is also affected under submerged soil due to prolonged reduced condition. Decrease in the activity of enzymes and microorganism 
reduced the availability of nutrient under submerged condition. Under submerged condition due to hypoxic environment the activity of nitrifying community is inhibited resulting in depletion of soil nitrogen which affects the crop productivity (Jaiswal and Srivastava, 2018). Therefore, the mineralisation of nitrogen in submerged soil is decreased under submerged soils. Flooding condition release the $\mathrm{P}$ in soil due to iron reduction but a secondary reaction between $\mathrm{Fe}^{2+}$ and $\mathrm{P}$ decrease the soluble P (Tian et al., 2017).

Sulphur reducing bacteria also reduces the $S$ under flooded condition and produced $\mathrm{H}_{2} \mathrm{~S}$ gas. $\mathrm{H}_{2} \mathrm{~S}$ is highly toxic by inhibiting the activity of cytochrome $\mathrm{c}$ oxidase in mitochondria, leading to a subsequent blocking of energy production in roots, and by inhibiting other metal containing enzymes (Lamers et al., 2012).Moreover, under flooded condition due to depletion of redox potential micronutrients such as $\mathrm{Fe}^{3+}$ and $\mathrm{Mn}^{4+}$ changed to $\mathrm{Fe}^{2+}$ and $\mathrm{Mn}^{2+}$ respectively and their solubility increase to toxic level which adversely damage the plant roots (Marashi, 2018). Similarly, high concentration of $\mathrm{Fe}^{2+}$ and $\mathrm{Mn}^{2+}$ were the major constraint in waterlogged soil under wheat belt in eastern Victoria (Sharma et al., 2018).Aldanaet al. (2014) reported a significant decrease in plant height, leaf area, diameter of base stem, number of reproductive flower and dry weight in gooseberry with increasing number of waterlogging days. Renet al. (2014) reported that decreased in grain per ear, 1000 grain weight, plant height, ear height and leaf area index due to waterlogging in maize crop. Similarly, Guanget al. (2012) also found a negative correlation in between the seed cotton yield and waterlogging.

\section{Heavy metal stress}

Heavy metal stress becomes a major problem in crop production worldwide. Now days with industrialization and urbanization, a large amount of chemical input is added to soil and water bodies (Rai et al., 2019). This huge amount of chemical increases the concentration of heavy metal in soil and water bodies. These heavy metals pollute the soil and water bodies which result in metal toxicity. Heavy metalstoxicity affects the crop productivity by affecting the physical and chemical properties of soil (Sethy and Ghosh, 2013). Heavy metal destroys the soil structure, fluctuate the $\mathrm{pH}$ of soil, decrease the plant uptake by affecting its physiological and metabolic activities.

Heavy metals such as $\mathrm{Zn}, \mathrm{Cu}, \mathrm{Fe}, \mathrm{Mo}, \mathrm{Ni}$ and Co are considered essential for plants but certain heavy metals such as $\mathrm{Ar}, \mathrm{Pb}, \mathrm{Cd}, \mathrm{Hg}$ and $\mathrm{Cr}$ affects the plants normal growth and development and decrease the crop productivity (Tiwari and Lata, 2018). Ar exits in two form i.e. $\operatorname{Ar}(\mathrm{III})$ and $\operatorname{Ar}(\mathrm{V})$, out of which $\operatorname{Ar}(\mathrm{V})$ is more toxic by affecting the normal functioning of plant by generating reactive oxygen species (Verma et al., 2016). $\mathrm{Pb}$ is non-biodegradable and its long presence in soil affects the plant and animal growth by affecting the activities of enzymes such as ADPase and ATPase. Pb also affects the seed germination, seedling development and transpiration process in plant (Kumar et al., 2017). Cd is highly soluble in water and easily taken up by plants. After entering in the central cylinder, the metal flows through xylem and move towards aerial part via water. Inside xylem, $\mathrm{Cd}$ binds with amino acids and form complexes which are highly toxic to plants (Rascio and Navari-Izzo, 2011).Even at low concentrations $\mathrm{Cd}$ can severely alter several enzyme activities including those involved in the Calvin cycle, carbohydrate and phosphorus metabolism, and $\mathrm{CO}_{2}$ fixation ultimately resulting in stunted growth, chlorosis, leaf epinasty, alterations in chloroplast ultrastructure, inhibition of photosynthesis and pollen germination and 
tube growth, induction of lipid peroxidation, and alterations in nitrogen $(\mathrm{N})$ and sulfur $(\mathrm{S})$ metabolism and disruption of antioxidant machinery (Tiwari and Lata, 2018). Zhou et al.(2007) reported that lower concentration of $\mathrm{Hg}$ is not toxic to plants but the higher concentration is highly phytotoxic to plants cell and cause other physiological disorders.

Heavy metals also affect the soil biota through microbial process and soil-microbe interaction. It reduces the soil microbial biomass and enzyme activity which slow down the process of soil organic matter decomposition (Gall et al., 2015). Slow organic matter decomposition result in decrease in soil respiration rate. Nwuche and Ugoji (2008) found a significant decrease in the soil microbial biomass and low $\mathrm{CO}_{2}$ evolution with respect to $\mathrm{Cu}$ and $\mathrm{Cu}: \mathrm{Zn}$ amendment. Plant metabolic activity such as photosynthesis and chlorophyll content are also affected by heavy metals toxicity. They altered the normal functioning of $\mathrm{RuBisCo}$ enzyme (Shahid et al., 2015) and inhibit the electron transport between PS I and PS II. Kuzminovet al. (2013) noticed that $\mathrm{Cd}$ and $\mathrm{Cu}$ caused reticence of electron transport between PSI and PSII, followed by a reduction in the energy transfer in lightharvesting complexes, indicating metal effects on the functional integrity of the lipid membranes.

Heavy metals affect the physiological, morphological, chemical and biological process in plants which cause reduction in yield. Toxicity of heavy metal results in poor seed germination and seedling establishment. Heavy metals are reported to retard the seed germination by affecting the digestion and mobilization of seed food reserve which reduce the plant height, root length, fresh and dry weight, chlorophyll and enzymes activity which ultimately reduce the crop yield (Sethy and Ghosh, 2013). Reduction in the yield of sunflower due to the synthesis of ROS and reduce catalase activity by the $\mathrm{Cu}$ toxicity is reported by Pena et al., 2011.Ghani (2010) reported decreased dry matter and seed yield, reduced nitrogen content in plant tissues, and lowered protein content in seeds of maize under treatment of heavy metal. Fathiet al. (2011) found a negative effect on the absorption of $\mathrm{Zn}$ in wheat crop and decrease in the yield and fry matter in wheat crop with higher Cd level. Okoyeet al. (2019) also found a significant delay in emergence of seedling and reduction in yield of African yarn bean due to $\mathrm{Cd}$ toxicity. $\mathrm{Cu}$ (2015) also found $25 \%, 31 \%$ and $44 \%$ reduction in plant height and $27 \%, 51 \%$ and $56 \%$ in yield of Brassica juncea at $50 \mathrm{ppm}, 100 \mathrm{ppm}$ and 200ppm dose of $\mathrm{Pb}$.

In conclusion, abiotic stress becomes a major problem in crop production now days. Abiotic stress such as extreme temperature, salinity, flood, heavy metals, etc. reduces the crop yield by affecting physical, chemical and biological properties of soil as well as plants. Under different type of abiotic stress, the normal functioning of plant is affected in different ways.

Plants had developed special modification to overcome the effect of abiotic stress such as osmotic adjustment under high saline condition, antioxidant enzymes and reduction in area of leaf to reduce transpiration loses. But, under extreme condition these modification fails and significant reduction in crop yield was reported. Under these conditions, mechanical methods are adopted to reduce the impact of abiotic stress. Genetic engineering, microorganism, bio-char, drainage of standing water, etc. are the mechanical measures which are to be adopted to overcome the effects of abiotic stress. Some mechanical measure are laborious and costly, so alternative measure needs to be developed. 


\section{References}

Abdeshahian, M., Nabipour, M. and Meskarbashee, M., 2010.Chlorophyll fluorescence as criterion for the diagnosis salt stress in wheat (Triticum aestivum) plants. Int. J. Chem. Biol. Eng, 4: 184-186.

Abeer, H., Abd_Allah, E.F., Alqarawi, A.A., ElDidamony, G., Alwhibi, M., Egamberdieva, D. and Ahmad, P., 2014. Alleviation of adverse impact of salinity on faba bean (Viciafaba L.) by arbuscularmycorrhizal fungi. Pak. J. Bot, 46(6): 2003-2013.

Abid, G., M'hamdi, M., Mingeot, D., Aouida, M., Aroua, I., Muhovski, Y., Sassi, K., Souissi, F., Mannai, K. and Jebara, M., 2017.Effect of drought stress on chlorophyll fluorescence, antioxidant enzyme activities and gene expression patterns in faba bean (Vicia faba L.). Archives of Agronomy and Soil Science, 63(4): 536-552.

Aldana, F., García, P.N. and Fischer, G., 2014. Effect of waterlogging stress on the growth, development and symptomatology of cape gooseberry (Physalis peruviana L.) plants. Revista de la Academia Colombiana de Ciencias Exactas, Físicas y Naturales, 38(149): 393-400.

Ashraf, M., 2009.Biotechnological approach of improving plant salt tolerance using antioxidants as markers. Biotechnology advances, 27(1): 84-93.

Ashraf, M.A., 2012. Waterlogging stress in plants: A review. African Journal of Agricultural Research, 7(13): 1976-1981.

Aydinşakir, K., BüyüktaŞ, D., Nazmi, D.İ.N.Ç. and Karaca, C., 2015. Impact of salinity stress on growing, seedling development and water consumption of peanut (Arachis hypogaea cv. NC-7). Akdeniz ÜniversitesiZiraatFakültesiDergisi, 28(2).

Barlow, K.M., Christy, B.P., O’leary, G.J., Riffkin, P.A. and Nuttall, J.G., 2015. Simulating the impact of extreme heat and frost events on wheat crop production: A review. Field Crops Research, 171 :109119.

Bhattacharyya, P., Chakrabarti, K. and Chakraborty, A., 2005. Microbial biomass and enzyme activities in submerged rice soil amended with municipal solid waste compost and decomposed cow manure. Chemosphere, 60(3): 310-318.

Bita, C. and Gerats, T., 2013. Plant tolerance to high temperature in a changing environment: scientific fundamentals and production of heat stress-tolerant crops. Frontiers in plant science, 4: 273.

Cattivelli, L., Rizza, F., Badeck, F.W., Mazzucotelli, E., Mastrangelo, A.M., Francia, E., Marè, C., Tondelli, A. and Stanca, A.M., 2008. Drought tolerance improvement in crop plants: an integrated view from breeding to genomics. Field Crops Research, 105(1-2): 1-14.

Commuri, P.D. and Jones, R.J., 2001. High temperatures during endosperm cell division in maize. Crop Science, 41(4): 1122-1130.

$\mathrm{Cu}$, N.X., 2015. Effect of Heavy metals on plant growth and ability to use fertilizing substances to reduce heavy metal accumulation by Brassica juncea $\mathrm{L}$. Czern. Global Journal of Science Frontier Reasearch, 15(3): 35-41.

Dong, S., Jiang, Y., Dong, Y., Wang, L., Wang, W., Ma, Z., Yan, C., Ma, C. and Liu, L., 2019.A study on soybean responses to drought stress and rehydration. Saudi Journal of Biological Sciences, 26(8): 2006-2017.

Dupuis, I. and Dumas, C., 1990. Influence of temperature stress on in vitro fertilization and heat shock protein synthesis in maize (Zea mays L.) reproductive tissues. Plant physiology, 94(2): 665-670.

Egamberdieva, D., Jabborova, D. and Wirth, S., 2013. Alleviation of salt stress in legumes by co-inoculation with Pseudomonas and Rhizobium. In Plant microbe symbiosis: Fundamentals and advances (291-303). Springer, New Delhi.

Fahad, S., Bajwa, A.A., Nazir, U., Anjum, S.A., Farooq, A., Zohaib, A., Sadia, S., Nasim, W., Adkins, S., Saud, S. and Ihsan, M.Z., 2017. Crop production under drought and heat stress: plant responses and management options. Frontiers in plant science, 8: 1147.

Fang, X., Turner, N.C., Yan, G., Li, F. and Siddique, K.H., 2010. Flower numbers, pod production, pollen viability, and pistil 
function are reduced and flower and pod abortion increased in chickpea (Cicerarietinum L.) under terminal drought. Journal of experimental botany, 61(2): 335-345.

Farooq, M., Wahid, A., Kobayashi, N., Fujita, D.B.S.M.A. and Basra, S.M.A., 2009. Plant drought stress: effects, mechanisms and management. In Sustainable agriculture (153-188).Springer, Dordrecht.

Fathi, G., Irashahi, Z., Moosavi, S.A., Gharineh, M.H. and Siadat, S.A., 2011.Effects of different cadmium and zinc concentrations on yield and nutrient uptake of wheat. EFITA/WCCA, 11.

Ferreira, R.G., Tavora, F.J.A.F. and Hernandez, F.F.F., 2001. Dry matter partioning and mineral composition of roots, stems and leaves of guava grown under salt stress conditions. PesquisaAgropecuariaBrasileir $a$ (Brazil).

Ferris, R., Ellis, R.H., Wheeler, T.R. and Hadley, P., 1998. Effect of high temperature stress at anthesis on grain yield and biomass of field-grown crops of wheat. Annals of Botany, 82(5): 631-639.

Ferronato, C., Marinari, S., Francioso, O., Bello, D., Trasar-Cepeda, C. and Antisari, L.V., 2019.Effect of waterlogging on soil biochemical properties and organic matter quality in different salt marsh systems. Geoderma, 338: 302-312.

Food and Agriculture Organization of the United Nations [FAO] (2017). The Impact of Disasters and Crises on Agriculture and Food Security.Rome: FAO, 168.

Frederiks, T.M., Christopher, J.T. and Borrell, A.K., 2008. Low temperature adaption of wheat post head-emergence in northern Australia.

Gall, J.E., Boyd, R.S. and Rajakaruna, N., 2015. Transfer of heavy metals through terrestrial food webs: a review. Environmental monitoring and assessment, 187(4): 201.

Ghani, A., 2010. Toxic effects of heavy metals on plant growth and metal accumulation in maize (Zea mays L.).

Greaves, J.A., 1996.Improving suboptimal temperature tolerance in maize-the search for variation. Journal of experimental botany, 47(3): 307-323.
Greenway, H., Armstrong, W. and Colmer, T.D., 2006.Conditions leading to high $\mathrm{CO}_{2}$ (>5 $\mathrm{kPa}$ ) in waterlogged-flooded soils and possible effects on root growth and metabolism. Annals of Botany, 98(1): 9-32.

Gu, C., Zhang, S., Han, P., Hu, X., Xie, L., Li, Y., Brooks, M., Liao, X. and Qin, L., 2019. Soil enzyme activity in soils subjected to flooding and the effect on nitrogen and phosphorus uptake by Oilseed rape. Frontiers in Plant Science, 10: 368.

Guang, C., Xiugui, W., Yu, L. and Wenbing, L., 2012. Effect of water logging stress on cotton leaf area index and yield. Procedia Engineering, 28: 202-209.

Hao, X., Li, P., Feng, Y., Han, X., Gao, J., Lin, E. and Han, Y., 2013. Effects of fully open-air [CO2] elevation on leaf photosynthesis and ultrastructure of Isatisindigotica Fort. PLoS One, 8(9).

Hatfield, J.L. and Prueger, J.H., 2015. Temperature extremes: Effect on plant growth and development. Weather and climate extremes, 10: 4-10.

Hatfield, J.L., Boote, K.J., Kimball, B.A., Ziska, L.H., Izaurralde, R.C., Ort, D., Thomson, A.M. and Wolfe, D., 2011. Climate impacts on agriculture: implications for crop production. Agronomy journal, 103(2): 351-370.

Hirt, H. and Shinozaki, K., 2003. Plant responses to abiotic stress (Vol. 4). Springer Science $\&$ Business Media.

Hussain, H.A., Men, S., Hussain, S., Chen, Y., Ali, S., Zhang, S., Zhang, K., Li, Y., Xu, Q., Liao, C. and Wang, L., 2019. Interactive effects of drought and heat stresses on morpho-physiological attributes, yield, nutrient uptake and oxidative status in maize hybrids. Scientific reports, 9(1): 112.

Hussain, M., Malik, M.A., Farooq, M., Ashraf, M.Y. and Cheema, M.A., 2008.Improving drought tolerance by exogenous application of glycinebetaine and salicylic acid in sunflower. Journal of Agronomy and Crop Science, 194(3): 193-199.

Jaiswal, A. and Srivastava, J.P., 2018. Changes in reactive oxygen scavenging systems and protein profiles in maize roots in response to nitric oxide under waterlogging stress. 
Jaleel, C.A., Manivannan, Paramasivam., W, A., Farooq, M., Al-Juburi, H.J., Somasundaram, Ramamurthy. and Panneerselvam, R., 2009. Drought stress in plants: a review on morphological characteristics and pigments composition. Int. J. Agric. Biol, 11(1): 100105.

Kakani, V.G., Reddy, K.R., Koti, S., Wallace, T.P., Prasad, P.V.V., Reddy, V.R. and Zhao, D., 2005. Differences in in vitro pollen germination and pollen tube growth of cotton cultivars in response to high temperature. Annals of botany, 96(1): 5967.

Keyvan, S., 2010. The effects of drought stress on yield, relative water content, proline, soluble carbohydrates and chlorophyll of bread wheat cultivars. J. Anim. Plant Sci, 8(3): 1051-1060.

Khan, M.A., 2001.Experimental assessment of salinity tolerance of Ceriopstagal seedlings and saplings from the Indus delta, Pakistan. Aquatic Botany, 70(3): 259-268.

Kim, H.Y., Horie, T., Nakagawa, H. and Wada, K., 1996. Effects of elevated CO2 concentration and high temperature on growth and yield of rice: II. The effect on yield and its components of Akihikari rice. Japanese Journal of Crop Science, 65(4): 644-651.

Kumar, B., Smita, K. and Flores, L.C., 2017. Plant mediated detoxification of mercury and lead. Arabian Journal of Chemistry, 10: S2335-S2342.

Kumudini, S., Andrade, F.H., Boote, K.J., Brown, G.A., Dzotsi, K.A., Edmeades, G.O., Gocken, T., Goodwin, M., Halter, A.L., Hammer, G.L. and Hatfield, J.L., 2014. Predicting maize phenology: intercomparison of functions for developmental response to temperature. Agronomy Journal, 106(6): 2087-2097.

Kunito, T., Shiroma, T., Moro, H. and Sumi, H., 2018. Annual Variation in Soil Enzyme Activity in a Paddy Field: Soil Temperature and Nutrient Availability Are Important for Controlling Enzyme Activities. Applied and Environmental Soil Science, 2018.

Kuzminov, F.I., Brown, C.M., Fadeev, V.V. and
Gorbunov, M.Y., 2013. Effects of metal toxicity on photosynthetic processes in coral symbionts, Symbiodinium spp. Journal of experimental marine biology and ecology, 446: 216-227.

Lamers, L.P., Van Diggelen, J.M., Op Den Camp, H.J., Visser, E.J., Lucassen, E.C., Vile, M.A., Jetten, M.S., Smolders, A.J. and Roelofs, J.G., 2012. Microbial transformations of nitrogen, sulfur, and iron dictate vegetation composition in wetlands: a review. Frontiers in microbiology, 3: 156.

Lobell, D.B., Schlenker, W. and Costa-Roberts, J., 2011.Climate trends and global crop production since 1980. Science, 333(6042): 616-620.

Luo, Q., 2011. Temperature thresholds and crop production: a review. Climatic Change, 109 (3-4): 583-598.

Manik, S.N., Pengilley, G., Dean, G., Field, B., Shabala, S. and Zhou, M., 2019. Soil and crop management practices to minimize the impact of waterlogging on crop productivity. Frontiers in plant science, 10.

Marashi, S.K., 2018. Evaluation of uptake rate and distribution of nutrient ions in wheat (Triticum aestivum L.) under waterlogging condition. Plant Physiology, 8(4): 25392547.

Meloni, D.A., Oliva, M.A., Ruiz, H.A. and Martinez, C.A., 2001.Contribution of proline and inorganic solutes to osmotic adjustment in cotton under salt stress. Journal of Plant Nutrition, 24(3): 599-612.

Mohammed, A.R. and Tarpley, L., 2011. Effects of high night temperature on crop physiology and productivity: Plant growth regulators provide a management option. Global Warming Impacts-Case Studies on the Economy, Human Health, and on Urban and Natural Environments: 53-172.

Munns, R. and Tester, M., 2008.Mechanisms of salinity tolerance. Annu. Rev. Plant Biol., 59: 651-681.

Naim, A.M., Mohammed, K.E., Ibrahim, E.A. and Suleiman, N.N., 2012.Impact of salinity on seed germination and early seedling growth of three sorghum (Sorghum biolor L. Moench) cultivars. Science and 
Technology, 2(2): 16-20.

Nwuche, C.O. and Ugoji, E.O., 2008. Effects of heavy metal pollution on the soil microbial activity. International Journal of Environmental Science \& Technology, 5(3): 409-414.

Okoye, P.C., Anoliefo, G.O., Ikhajiagbe, B., Ohanmu, E.O., Igiebor, F.A. and Ephraim, A.L.I.U., 2019. Cadmium toxicity in African yam bean (Sphenostylis stenocarpa (HOCHST. EX A. RICH.)HARMS genotypes. ActaagriculturaeSlovenica, 114( 2): 205-220.

Parida, A.K. and Das, A.B., 2005. Salt tolerance and salinity effects on plants: a review. Ecotoxicology and environmental safety, 60(3): 324-349.

Pena, L.B., Azpilicueta, C.E. and Gallego, S.M., 2011. Sunflower cotyledons cope with copper stress by inducing catalase subunits less sensitive to oxidation. Journal of Trace Elements in Medicine and Biology, 25(3): 125-129.

Pettigrew, W.T., 2008. The effect of higher temperatures on cotton lint yield production and fiber quality. Crop science, 48(1): 278285

Rai, P.K., Lee, S.S., Zhang, M., Tsang, Y.F. and Kim, K.H., 2019. Heavy metals in food crops: Health risks, fate, mechanisms, and management. Environment

international, 125: 365-385.

Rascio, N. and Navari-Izzo, F., 2011. Heavy metal hyperaccumulating plants: how and why do they do it? And what makes them so interesting?. Plant science, 180(2): 169181.

Ren, B., Zhang, J., Li, X., Fan, X., Dong, S., Liu, P. and Zhao, B., 2014. Effects of waterlogging on the yield and growth of summer maize under field conditions. Canadian Journal of plant science, 94: 23-31.

Salehi-Lisar, S.Y. and Bakhshayeshan-Agdam, H., 2016. Drought stress in plants: causes, consequences, and tolerance. In Drought Stress Tolerance in Plants,1:1-16.Springer, Cham.

Samarah, N.H., 2005. Effects of drought stress on growth and yield of barley.

Sanghera, G.S., Wani, S.H., Hussain, W. and
Singh, N.B., 2011.Engineering cold stress tolerance in crop plants. Current genomics, 12(1): 30 .

Sasidharan, R., Bailey-Serres, J., Ashikari, M., Atwell, B.J., Colmer, T.D., Fagerstedt, K., Fukao, T., Geigenberger, P., Hebelstrup, K.H., Hill, R.D. and Holdsworth, M.J., 2017.Community recommendations on terminology and procedures used in flooding and low oxygen stress research. New Phytologist, 214(4): 14031407.

Sethy, S.K. and Ghosh, S., 2013. Effect of heavy metals on germination of seeds. Journal of natural science, biology, and medicine, 4(2): 272.

Shahid, M., Khalid, S., Abbas, G., Shahid, N., Nadeem, M., Sabir, M., Aslam, M. and Dumat, C., 2015. Heavy metal stress and crop productivity.In Crop production and global environmental issues (125).Springer, Cham.

Sharma, S.K., Kulshreshtha, N., Kumar, A., Yaduvanshi, N.P.S., Singh, M., Prasad, K.R.K. and Basak, N., 2018.Waterlogging effects on elemental composition of wheat genotypes in sodic soils. Journal of Plant Nutrition, 41(10): 1252-1262.

Sheldon, A.R., Dalal, R.C., Kirchhof, G., Kopittke, P.M. and Menzies, N.W., 2017.The effect of salinity on plantavailable water. Plant and Soil, 418(1-2): 477-491.

Shimono, H., Okada, M., Kanda, E. and Arakawa, I., 2007. Low temperature-induced sterility in rice: Evidence for the effects of temperature before panicle initiation. Field crops research, 101(2): 221-231.

Shrivastava, P. and Kumar, R., 2015. Soil salinity: a serious environmental issue and plant growth promoting bacteria as one of the tools for its alleviation. Saudi journal of biological sciences, 22(2): 123-131.

Siddiqui, M.H., Al-Khaishany, M.Y., Al-Qutami, M.A., Al-Whaibi, M.H., Grover, A., Ali, H.M., Al-Wahibi, M.S. and Bukhari, N.A., 2015.Response of different genotypes of faba bean plant to drought stress. International Journal of Molecular Sciences, 16(5): 10214-10227.

Singh, V., Nguyen, C.T., van Oosterom, E.J., 
Chapman, S.C., Jordan, D.R. and Hammer, G.L., 2015. Sorghum genotypes differ in high temperature responses for seed set. Field Crops Research, 171: 32-40.

Tian, J., Dong, G., Karthikeyan, R., Li, L. and Harmel, R.D., 2017.Phosphorus dynamics in long-term flooded, drained, and reflooded soils. Water, 9(7): 531.

Tiwari, S. and Lata, C., 2018. Heavy metal stress, signaling, and tolerance due to plantassociated microbes: an overview. Frontiers in plant science, 9: 452.

Tuteja, N., Gill, S.S. and Tuteja, R., 2011. Plant responses to abiotic stresses: shedding light on salt, drought, cold and heavy metal stress. Omics and Plant Abiotic Stress Tolerance, 1: 39-64.

Ugarte, C., Calderini, D.F. and Slafer, G.A., 2007. Grain weight and grain number responsiveness to pre-anthesis temperature in wheat, barley and triticale. Field Crops Research, 100(2-3): 240-248.

Verma, S., Verma, P.K., Meher, A.K., Dwivedi, S., Bansiwal, A.K., Pande, V., Srivastava, P.K., Verma, P.C., Tripathi, R.D. and Chakrabarty, D., 2016. A novel arsenic methyltransferase gene of Westerdykellaaurantiaca isolated from arsenic contaminated soil: phylogenetic, physiological, and biochemical studies and its role in arsenic bioremediation. Metallomics, 8(3): $344-$ 353.

Vijayalakshmi, D., 2018. Abiotic stresses and its management in agriculture. TNAU Agritech, Coimbatore.

Wang, C., Linderholm, H.W., Song, Y., Wang, F., Liu, Y., Tian, J., Xu, J., Song, Y. and Ren, G., 2020. Impacts of Drought on Maize and Soybean Production in Northeast China During the Past Five Decades. International Journal of Environmental Research and Public Health, 17(7): 2459.

Yoshida, S., 1981. Fundamentals of rice crop science. Int. Rice Res. Inst..

Zhou, Z.S., Huang, S.Q., Guo, K., Mehta, S.K., Zhang, P.C. and Yang, Z.M., 2007. Metabolic adaptations to mercury-induced oxidative stress in roots of Medicago sativa L. Journal of inorganic biochemistry, 101(1): 1-9.

Zinn, K.E., Tunc-Ozdemir, M. and Harper, J.F., 2010. Temperature stress and plant sexual reproduction: uncovering the weakest links. Journal of experimental botany, 61(7): 1959-1968.

\section{How to cite this article:}

Deepak Kochar, Sushil and Rahul. 2020. A Review on the Impact of Abiotic Stress on Plant Growth and Crop Production. Int.J.Curr.Microbiol.App.Sci. 9(07): 3958-3970. doi: https://doi.org/10.20546/ijcmas.2020.907.465 